\title{
Development of Secondary School Students' Generic Structure Execution in Personal Experience Recount Writing Texts through SFL Genre-based Approach
}

\author{
Pajonsak Mingsakoon ${ }^{1 *}$, Udomkrit Srinon ${ }^{2}$ \\ ${ }^{1}$ PhD Candidate, Faculty of Liberal Arts and Science, Kasetsart University, Kampaeng Saen Campus, Nakorn Pathom, Thailand \\ ${ }^{2}$ PhD, Faculty of Liberal Arts and Science, Kasetsart University, Kamphaeng Saen Campus, Nakorn Pathom, Thailand
}

Corresponding Author: Pajonsak Mingsakoon, E-mail: bmingsakoon@yahoo.com

\section{ARTICLE INFO}

Article history

Received: August 17, 2018

Accepted: October 23, 2018

Published: December 28, 2018

Volume: 9 Issue: 6

Advance access: November 2018

Conflicts of interest: None

Funding: None

\section{Key words:}

Secondary School Students,

Generic Structure,

Personal Experience Recount,

Modeling Text,

Text Construction,

Conformity,

SFL Genre-based Approach

Dialogic Expansion,

CODA

\begin{abstract}
This paper is a partial fulfillment of the dissertation undertaken with the case study of teaching writing recounts for the EFL Thai upper secondary school students with SFL genre-based approach at Hunkhapittayakom Secondary School, Hunkha District, Chainat Province, Thailand, the second semester of the academic year 2015. This study focused on the analysis of students' generic structure development of recount writing texts through SFL perspective. Teaching of personal experience recount genre using the teaching-learning cycle of the SFL genre-based approach was employed to 26 Mattayom Suksa five students. The analysis of the students' pretest writing texts showed that they could not control the structures of their texts in that these writing texts were non-conformed to the stages of recount writing, and the themes were sidetracked from the topic. However, when these students were exposed writing with the SFL genre-based approach, the analysis demonstrated that their personal experience recounts were positively developed with a higher degree of generic structure construction in terms of conformity when compared to the modeling texts of the literature review and the pretest texts at the commencement of the course. It was observable that all students could expand communicative details and dialogic expansion in their final personal experience recount texts from such the orientation stage, the series of the events and the re-orientation stage with some CODA, argumentative elaboration. This is argued that SFL genre-based approach helps promote the students' understanding and writing ability about the meaning, purpose and organization of the personal experience recount texts insofar that they could independently execute the similar texts themselves in a more degree. The study suggested that the SFL genre-based approach should be promoted continuously to develop writing skill of secondary school students in all levels of education related or in other similar contexts.
\end{abstract}

\section{INTRODUCTION}

\section{Introduction and Problems}

A literature review (Feez, 2002; Derewianka, 2003; Halliday \& Matthiessen, 2004; Foley, 2005; LUU, 2011; Srinon, 2011) revealed that most studies addressed either particularly teaching writing or accurately using academic language to the EFL students in the tertiary educational level. Writing skill was the most difficult skill to teach Thai EFL students and mobilized educational institutes to engage with amendment of the students' academic literacy skills (Chinnawongs, 2001; Syananondh \& Padgate, 2005; Padgate, 2008).

Theoretically, there are many approaches and methods for teaching English writing and genre-based approach is one of the fruitful ideologies which has gained attention from educators and researchers around the world (Callaghan \& Rothery, 1993; Martin, 1993; Halliday, 1994; Paltridge, 2001, Christie \& Unsworth, 2006; Gibbon, 2007; Christie \& Derewianka, 2008; Thompson, 2014). In this regard, Johns
(2002) has implemented SFL genre-based approach with attempting to validate standard structures of the text and stages of rhetorical moves focusing on the varieties of grammatical features, to teach writing in K12 and at adult-learner levels. LUU (2011) employed six-staged language course with forty-five first year students of Finance-Marketing from Ho Chi Minh City University in Viet Nam to investigate the impacts of conducting reading skills to the students' learning. In Thailand, Srinon (2011) investigated that the generic structure development on writing 'exposition' and 'discussion' where it was found that apart from the prototype texts, some students constructed their texts in the form of the middle way of giving arguments which was an effect from the Thai culture through SFL genre-based approach with Thai university students.

As abovementioned, it is found that a few studies applied the SFL genre-based pedagogy to develop writing skill in the context of EFL Thai upper secondary school students, and most studies reinforced the needs to accelerate the devel- 
opment of English proficiency to obtain higher paying jobs and to pursue career advancement opportunities (Wiriyachitra, 2002; Foley, 2005). Based on the preliminary problems, Thai learners today must not only be trained for a better level of English competence but also that productive skills must be promoted in the country's educational system in order to challenge their communicative abilities beyond EFL and the global competition.

\section{Significance of the Study}

Regarding the needs to development using language for communication on the world stage, the benefits of SFL genre-based approach challenge Thai teachers to deploy certain suggested techniques by using modeling texts to guide student writers to understand the natural feature of texts before starting writing. Engagement with text structure and thematic focus reinforces those EFL secondary school students across the country to practice weaving texts systematically (Halliday \& Matthiessen, 2004). Significantly, Derewianka (2003) has argued that the texts used in daily life be adopted as the curriculum genre in schools to enhance using English for communication. Genre-based approach has been successfully applied in primary, secondary, tertiary curricula in programs for native speakers of English, ESL and EFL learners in different contexts from a great number of countries around the world (Callaghan \& Rothery, 1993; Martin, 1993; Halliday, 1994; Paltridge, 2001, Christie \& Unsworth, 2006; Gibbon, 2007; Christie \& Derewianka, 2008; Hood, 2010; Srinon, 2011; Payaprom, 2012, Yin, 2013).

\section{Aim and Goal of the Study}

This study is intended to present one of the critical analyses to discover how the students develop in their writing skills such as generic structures execution. This can reflect the overview of success in writing, where the students show how to control the structure of the texts to match with the structure of the modeling texts and their purposes. Certain educational work has been applied to reading and writing classes with the cycle of SFL genre-based approach (see also Christie, 2005; Unsworth, 2006) where the early element learners in an arts program accomplished writing goals of recounts by practicing stage by stage. During a de-contextualization stage, functional grammar constructs were introduced to pupils to engage with the notions and components latent in the texts (Martin \& Rose, 2003; Halliday \& Matthiessen, 2004).

\section{Research Questions}

The research questions were proposed to investigate the developed issues of the students' writing skill as follows:

In what ways does the SFL genre-based approach to teaching writing enhance students' text execution?
Do the students' personal experience recount products conform to the prototype texts as identified in the literature review?

\section{LITERATURE REVIEW}

\section{Personal Experience Recounts}

With the purposes of giving information or retelling the story, a personal experience recount is reviewed as a genre reflecting entertainments, showing opinions or feelings of being relaxed about the events through life experiences (Callaghan \& Rothery, 1993; Martin, 1993; Martin, 1997; Droga \& Humphrey, 2002). The first person narrator engaging with surrounding of specific participants and action processes in the sequences of time would retell or elaborate himself in a paticular situational culture (Gibbon, 2007; Martin \& Rose 2008; Ministry of Education, 2008; Hood, 2010).

\section{Generic Structures of Personal Experience Recount}

In regards to the generic structure, the personal experience recount is constructed into three ordering stages: Orientation, Series of Events and Re-orientation/CODA functionally organized in the following generic structure stages (Martin, 1993): Orientation ${ }^{\wedge}$ Sequence of Events ${ }^{\wedge}$ Re-orientation (optional element) which indicates the sequence of the elements of structure.

At the orientation stage, the writer gives background information and provides the setting for the story. The circumstances, such as places where the events occurred, the participants involved with the story and time focusing, are described at the beginning. The cause and objective of the situation are focused in order to attract readers. At the series of events-presentation stage, the writer always shadows the sequences of the series from the first event to the last one referring the circumstances such places and people. Finally, the stage of re-orientation focuses on an optional closure of the events. The writer always concludes the story directly by showing comments or attitudes towards the events so called CODA to justify value of the events in the personal experience recount (Droga \& Humphrey, 2002).

\section{Stages of Teaching-learning Cycle Applied from SFL Genre-based Approach}

In regard with the framework of SFL genre-based approach (Halliday, 1994; Paltridge, 2001; Christie, 2002; Derewianka, 2003; Martin \& Rose, 2003; Christie \& Unsworth, 2006; Martin \& Rose, 2008; Christie \& Maton, eds., 2011), the 'teaching-learning cycle' innovation in this study was designed into six stages in the following descriptions.

First, Building Knowledge of the Field is to work with general and peripheral meaning of the modeling texts and to engage the students with background of the meaning of the modeling texts and their own texts they are going to write. Second, Modeling Text is to make a discussion about the structural pattern and language feature of the selected re- 
count model texts and the events organized in the modeling texts by encouraging the students to order the events in the text through discussion. Third, De-contextualization and Organization is to elaborate and exemplify on the knowledge of word meaning and function identification appearing in the selected recount modeling text. Fourth, Joint Construction is to answer guided questions, to collect ideas and details about the modeling texts in group-works, reorder the jumbled events to rebuild a story of the recount and then discuss the construction of the recount text. Fifth, Independent Construction of a Text is to check the written texts in pairs by giving explanations with more examples and exchange ideas to develop language use and accuracy enhancing student confidence when writing individually or presenting works to the public. Sixth, Linking Related Text is to encourage the class to create different recounts by consulting both construction and the meaning of the modeling text they have read and the productive texts in the independent construction stage.

\section{RESEARCH METHOD}

To answer the research questions, the students' trends of text mobilizations required by the description in the standard modeling texts were selected for critical analysis because they are integral to whether and how the amended written texts are executed both structurally and meaningfully. With the case study design, the six student participants' posttest writing works of personal experience recounts were compared with their initial recounts in the pretest and the modeling text.

\section{Population}

The population of this study was derived from 189 Mattayom Suksa five students, in the age of 16-17 years old and having studied English for at least 12 years, six classes from $5 /$ special and $5 / 1$ to $5 / 5$.

\section{Research Sample}

The Mattayom Suksa 5 in the class of special program, with 26 students, was selected by convenience because it was assigned to the teacher researcher and fulfilled the requirement of the school curriculum for registering the English communicative writing course to the class.

\section{Participants}

The 26 students, from the abovementioned class, were classified by consulting the school academic English proficiency report and after analysis of the pretest writing by using the scoring rubric adapted from the recommendations of experts in SFL (Feez, 2002; Widodo, 2006; Martin and Rose, 2007; Christie and Derewianka, 2008 and Thompson, 2014). There were six participants in this case study: two students from the high group (HS1, HS2), two students from the middle group (MS1, MS2) and two students from the low group (LS1, LS2). The limitation of this report would be confined to the generic structure development respecting to the rec- ommendations of the modeling texts by comparing between the pretest and posttest products from the twelve writing products: six pretest writing- products from the selected participants and six posttest products of personal experience recounts from the same students.

\section{KEY FINDINGS AND INTERPRETATION}

\section{Pretest: Schemata of the Students' Generic Structure Execution}

On the pretest, three students (HS1, HS2 and MS1) could generally generate their recounts to match in some parts with the recommendations in the literature review on the structure of the modeling texts of recounts. This inferred that the generic structures of their recount texts on the pretest were 'conformed and compatible' to the motif text in some degrees. It indicated that these recount texts were not completely served with the qualifications of generic structure creation in the modeling texts. They presented some qualifications and evidences of text organization matching with the model in twofold. First, the recount texts showed complete components of recount structure but incompletely elaborated details to support the main idea in each stage of recount text such as beginning with orientation, following with body of the recount with a few series of events and closing with reorientation with very little information. Second, the texts were compatible with the purpose of the recount text in that the meaning of the produced texts still held the similar theme and context of the events. To clarify, these students, at the beginning of the course, could come up with ideas and understanding about the purpose of the recount focused on the Song Kran Festival in Thailand. For example, the HS1 wrote:

"...I was with my family on Song Kran day. In the morning, we gave food to the monks and then we let

the birds fly away in the sky and set the fish free in the river."

The written text in the orientation stage was matched with the majority of the text elaborated in the activities which most Thais did on Song Kran Day thoroughly. Nonetheless, the MS2 wrote nothing focusing on the title about Song Kran Festival:

"In Song Kran Festival yearly in hometown I party BBQ and my family and go to sea. I will zoo to

chonburi. 2 days I go to Bangkok and my friends and my friend go to concert music festival in

Bangkok and to eat fast food to 1.35 a.m. go to home in Bangkok 6.00 go to Chiangmai 12.00 pm eat food."

She usually lost control of the main idea in some places such as referring and rewinding to emphasize on the title of the text insofar her ideas about event generating were scattered into many topics where the minor trivialities of her text were sidetracked from the main idea. Notably, the transitivity became irrelevant to the topic focused at this stage because she projected different activities, e.g. having a party of $\mathrm{BBQ}$, going to the sea, visiting a zoo or going to concert in Bangkok and visiting Chiang Mai, from general Thai people do in such a special festival. 
At the end of the recount texts on the pretest, the HS1, HS2 and MS1 also provided one more part called 'Re-orientation' as described in the literature review. Notably, the HS1 had the re-orientation on the pretest text, and it was seemingly conformed to the recommendations of the modeling text. For this reason, HS1 immediately concluded the recount by giving positive argument of happiness about the festival. The CODA, she presented, was noticed from insisting the argument that "...happy and I had very good time.” The HS2 could provide ending details relevant to the purpose of the recount involved with the situations on Song Kran Festival in Thailand. She showed a CODA of feeling, e.g. "We are happy every time in the Song kran festival in Thailand..." with positive attitude towards Song Kran festival, e.g. "We are happy every time in the Song kran festival in Thailand. This festival has for a long time. Everyone should be preserved." This caused her text at re-orientation mostly conformed to the structure of the prototype text. However, the MS1 still repeated the events as described on the beginning stage. This conclusion seemed to make nothing special or attractive. For instance, she concluded the re-orientation with "In last day's Song Kran festival we did merit at the temple with mother's food again, mother met to cousin and had a conversation, then we get listened to sermon again..." This revealed that her text lacked of content development and creativity to motivate readers' attentions. That is to say, the phenomenon of creating the text at the re-orientation stage did not completely conform to the configurations of conclusion as described in the literature review.

On the other hand, the MS2, LS1 and LS2 in this case neither could write the recounts with regard to the gener ic structure of the recounts nor recreate the series plausibly. Their texts were classified in a low degree of generic structure execution. For example, the orientation of the LS2 was presented in that

"Song kran day. I go to the temple. with my family but my brother he want to go to the chainat water

park very much. but I am not go to the chainat. because I am so hot. My brother then go to the park

with my friends. My brother drive by pick-up go to chainat.... Tomorrow date 14 april I'm go to the

Ta-khaw-pod street with my friend. We have fun very much and we return to hunkha home... The end "Song kran day."

As can be seen, the LS2's writing work in the pretest was not conformed to the structure of the modeling text in that she retold her recount with very short elaboration. Regardless of the recount text organization, having few experiences of telling story and lacking knowledge of language construction, the LS2 produced her recount from the beginning to the end into only one big paragraph.

At the re-orientation stage, the MS2 and LS1 did generate some information into this section, but the meanings of the texts were not complete. For example, the MS2 wrote that

"I go to home but my friend surely wasn't. The last day Song Kran I did not go surely but go to

Wat... and my family or Song Kran day of. I then have that much."
She was likely to say something to conclude what she did on the Song Kran Festival after she had visited many places during the festival, e.g., going to Wat to make merit. However, it did not fully cover events, so it was reviewed as 'non-conformity,' she described at the previous part. Her text was executed with jumbled events organization and disregarded physical recount configuration.

To summarize, almost students in this case study had three sections in texts when developing their recounts on the pretest. Based on the analysis, referring to the scoring rubric recommended by the SFL framework, on the generic structure of the writing productions, the written texts are likely compatible to the structure of the prototype text outlined in the literature review. Nevertheless, their texts did not completely match with the recommendations in that some elements of text constructions such as the series of the events were created with either very few details or low coherence in homogenous concept organization and connection.

\section{Posttest: Students' Generic Structure Development in Personal Experience Recounts}

At the independent writing stage, the students were able to demonstrate a great number of developments in the posttest products by controlling the generic structure of their post-personal experience recount texts as the following descriptions.

\section{Stage of orientation}

In the orientation, the HS1 identified that the events happened 'On My Last Summer Vacation,' and the HS2 titled her recount as 'Good Memories in Kra Bee.' Focusing on the title of the texts and referring to the specific time could serve the purpose of the personal experience. Regarding the places, for instance, the HS1 retold that she went to do summer vacation activities in 'Pra Chuab Kiri Khan' province. The HS2 said that she visited Kra Bi with her family, e.g. "Last summer, I went to Kra Bee with my family." Of course, both of HS1 and HS2 had the similar orientation highlight by including members of their family joining on the trip. They shared good feeling and attitude towards the destinations, e.g., HS2 began her orientation text as:

"Last summer, I went to Kra Bee with my family. We went to this province by van... I felt excited

because it was my first time to travel to Kra Bee together with my family..."

Similarly, the MS1 focused on her personal experience recount with the title of the text as, 'Going to Plant the Forest,' and the MS2, titled her recount as 'Once on My Holiday.' The titles of the texts could lead the students to generate details in a united frame. This quality of writing was sustained throughout the whole text to match with the purpose of the personal experience recount retelling the past events. The MS1 highlighted on doing activities with friends and teachers, but MS2 replicated her situation at the orientation stage with the members of her family in that

"Last year, I went to Chon Buri with my family. There are four people travelling to this place... I 
was excited and happy to be with my family in Chon Buri because it was the first trip of my life...."

The LS1 retold her personal experience recount with the title of the text as, 'Ticket from the Sky,' and the LS2 titled her recount as 'Lucky Monday.' Both of the personal experience writing products were in the similar plot, getting free package of doing things for relax. The LS1 reminded that she was working in her office, and was going to have lunch with her friend, e.g., she said, “...It was my friend, Sandy. She asked me to go out at 11 o'clock. She wanted to have lunch with me at the restaurant... " In contrast, the LS2 retold that she had to go to school, and she had an appointment with her friend to hang out, e.g., she said, “...Last Monday,... I had to go to school. Suddenly, there was a ring call... in my cell phone. She asked me at 5.00 p.m. to go out after school... to watch movie in the cinema..."

\section{Stage of series of the events}

The HS1 greatly followed the suggestion of the modeling text by presenting the relations between the first location (the seafood market at Prachuap Kiri Khan) and the second place (the statues of our Kings at Ratchapak Park) as well as giving opinion about them. For instance,

"We went to pay respect to the statues of our Kings at Ratchapak Park in order to remind of their prosperity development for Thai people and the country. We believed that paying respect to the statues

of our Kings would bring happiness and good luck to our lives."

She also projected that the event occurred on sequential days by beginning the second event with "On the next day, we woke up early in the morning."

In the third event, the HS1 still could create the situations as compatibly as the suggestions of the prototype text by retelling what happened in the next place. She said that she went shopping and bought some souvenirs for her friends: "In the afternoon, my elder brother brought us to go shopping in HuaHin Samphannam floating market. I bought some souvenirs such as pencils and key chains for my friends at school." Then, she ended the event with visiting the sheep farm as she said in her text "After that we visited the sheep farm and learned about their lives at Swiss Ship Farm." Nevertheless, the HS2 differed from the HS1 by referring the recommendations of the people around her, e.g.,

"My grandfather ever told me that Khao Kha Nab Nam was the highlight symbol of the province. If

you did not visit Khao Kha Nab Nam, it meant you did not arrived Kra Bee."

In the fourth event, it was investigated that the HS1 omitted writing anything for this section, but the HS2 tried to follow the recommendations of the modeling text with extended this section by driving the Go-kart at the Kra Bee Kart Speed Way and taking some pictures for a memorial.

However, the MS1 did follow the suggestion of the modeling text by replicating the first location (... After that, we started to go to Khao Kha Yai. And, we arrived there at 9 o'clock...) in the second event. She could control her text with homogeneous framing where the situation in the first event was corresponded with the second one. Moreover, the MS1 used the word '...After that,...' to begin her second event making the texts connective chronologically and outstandingly promoting the timing connection.

In the third event, both of MS1 and MS2 could create the situations compatibly with the suggestions of the prototype text. The MS1 said that she carried out the planting project from the opening ceremony to end of the activity on that day. For example, she said,

"Next, we joined the opening ceremony and we took photos with the vice sheriff..., we picked up

young plants and we went to the planting area near the foot of the hill."

She also added some argumentative ideas towards the activity with good willing such as "We wished in the future the mountain was covered with the green forest." At the stage of the third event elaboration, the MS2 also shared higher feeling expression towards the activities she did in her recount. Notably, she commented the situation in this way, "...We had a great day. My parents sat smiling and laughing happily..." With higher detail elaboration, the MS1 could expand her personal experience in the fourth event as follows:

"In the afternoon, our teacher brought us to go shopping in the Lotus Department Store, Chainat. We

bought some food and some drinks to eat at home. Next, we went back to the School. We arrived the School at 2 p.m."

This event was expanded with activities of going shopping and going back to school with a nice connecting, for instance, the subordinating conjunctions such as 'In the afternoon...' and 'Next...,' the students deployed to organize the clauses in the event show that the story was both chronologically ordered and on track.

For the low students' writing works, the LS1 could interestingly generate certain details in the first event about how to get to the restaurant and identify the reason why they decided to go to the destination on foot, e.g., "Because the restaurant was not far away from our office, we decided to walk there." She described the event with very exciting details by presenting feeling of gladness because she and her friend found a free ticket to travel somewhere. So, she said,

"While we were going out to the restaurant, I saw colorful papers on the table. I took them and started

to read. We were shocked because they were tickets for visiting Khao Kheaw Open Zoo in the following day."

Her text appeared a surprising twist by not mentioning the restaurant but paying attention to a free touring package they found instead.

In the second event, the LS1 could effectively link the situation with the first one. She wrote that she and her friend were great because they found the free tickets. They decided not to have lunch but to go for a free trip in Khao Kheaw Open Zoo. They were lucky that they did not have to pay more for the trip. This was described in her text as follow:

"We were happy because the following day would be the holiday. We went home and prepared for the trip. We were very excited." 
Likewise, the LS2 controlled the second event as the LS1 did. That is to say, she could relate the details to the second event as what she said in the previous one. She began the second event with "...Being surprised, a particular day we found that the tickets were not used...." She and her friend showed a great feeling and excitement when finding free tickets, i.e., "Oh my God! We thought today was a lucky day for us."

In the third event, linking with the second event, the LS1 was able to present her feeling towards the places she visited as "...We jumped out of the car to get pretty fresh air. The weather at here was cool...," reflecting how cheerful she thought about the atmosphere around the zoo. She also chronologically linked this event with "...Later, we went inside the zoo. We saw tigers, lions,... We learned animal's behaviors."

\section{Stage of re-orientation}

Actually, both HS1 and HS2 could make conclusions in their re-orientations addressing the suggestions in the prototype text. According to the original re-orientation texts of the HS1 and HS2, it is interesting that both students elaborated that they felt happy to visit the places they planned and to encounter certain exciting activities. At the end of the texts, she relied on her brother's projection about attractive scenery, e.g., "I strongly agreed with my elder brother that Prachuap Kiri Khan had a great scenery..." The HS2 presented her ideas at the end of the personal experience recount as similarly as the HS1 did. She exposed that she agreed with her parents' projection in that Kra Bee was a really impressive place to visit. It replicated her feeling of fascination about each situation she described in this recount, e.g., "I supported my parents" thought idea that Kra Bee was a fascinating place. " Furthermore, the HS1 also added CODA to close their recounts by promising to visit these places again. She insisted, "I promised with myself that I would go there someday. "It reinforced life experiences as well as emphasized on both attention and engagement to accomplish the goals in minds. On the other hand, the MS2 confirmed that, "I promised to come back again." In other words, the MS1 evaluated the event that, “... it was a real fun. I had a great memory...” She also had a nice exemplum of CODA at the re-orientation by referring to having the opportunities to visit the zoo as she planned in the third event by insisting to return to travel in the same places some day. Likewise, the LS1 and LS2 completely presented the CODA in this stage. For example, the LS1 confirmed that she and her friend were so happy with the event that they would be back to visit that place again, e.g., "We were very happy for this trip, and we thought that we would go there again." She insisted that she was happy because of getting free tickets incidentally with "... We watched movie very happily. Suddenly, we thought we were very lucky because few people got such a good luck."

\section{DISCUSSIONS}

The analysis of the students' recount writings in the pretest revealed that the students in the middle group and the low group began with writing the recounts, rarely conformed to the generic structure outlined in the prototypes under the framework of SFL. For example, some writing works were organized in only one paragraph, and the meaning of the series of the events was sidetracked to the orientation and re-orientation. It might be argued that students merely dealt with practice writing by concerning with form and usage, not working with structure construction of genre (Chinnawongs, 2001), or Thai culture with the middle way of presenting ideas when writing caused the students' short paragraph execution (Srinon, 2011).

However, after these students had been engage with the SFL genre-based approach, they could write the personal experience to conform to those genre-staging prototypes. All students could execute their personal experience recounts by giving the background of the story in the orientation, linking the story to the series of the events with more complete details elaboration and structurally coherent generation and concluding the story at the re-orientation with some argumentative ideas and CODAs at the end of the recounts (Christie, 2005). The analysis showed that there had been some significant developments in the students' generic structure constructions of the recount texts across the duration of the course, and it seemed to be satisfactory insofar as the deployment of SFL genre-based approach increased positive connection between understanding modeling texts and generic structure development (Hammond and Gibbon, 2001). For this reason, all students were not only engaged with the register of the modeling text in the stage of building knowledge of a text but also they were concentrated with learning exercises about notions of words, language and text structures at the stage of de-contextualization and organization as discussed in the SFL teaching-learning cycling stages. The activities and language exercises in those teaching stages were to help the students concentrate and understand how the modeling texts were meaningfully constructed. It is also argued that the stages of building knowledge of a text and de-contextualization and organization are so beneficial that the students in this case were confident when beginning to write their texts independently because they were engaged with the elements of the language meaning and organization of the modeling texts as well as possible. As a result, their recount texts were positively developed in terms of purposive compatibility through learning both meaning and scaffolding of the recount modeling texts which positively made as well as they could make sense of their personal experience recount writing texts (Hyon, 1996). Feez (2002) also discussed the benefits of implementing modeling texts for teaching writing in that they give the greatest opportunities for learners to unfold the meanings of the context and situation embedded in the texts and encourage learners to expand details in the productive texts subsequently.

In conclusion, all participants (HS1, HS2, MS1, MS2, LS1, LS2) could produce personal experience recounts with interesting creation of event plotting addressing the suggestions of the modeling text provided for them when learning the stage of independent construction of a text. Their personal experience recounts are more communicative than the pretest writing products on account of having the opportunities to consult the 
idea organization and generic structuring of the modeling text through the stages of SFL genre-based approach. They did not completely mimic the modeling texts, but they tried the best to make the posttest texts structurally coherent and meaningful.

\section{CONCLUSIONS}

Regarding the aims and the results of the study, the students' posttest writing works of personal experience recounts were developed significantly in terms of generic structure execution than the ones in the pretest. For the analysis of writing works in the pretest, it revealed that the generic structures of the students' writing works of personal experience recounts were not conformed to the structure of the general personal experience recount texts. For example, their texts were too short and meaningless because of being totally written in only one paragraph that most of the texts were both less communicable and incompatible to the prototype of the generic structure of the personal experience recount genre as identified in the literature. Interestingly, when the students had been exposed to write this genre with the teaching stages under the framework of the SFL genre-based approach, the generic structures of their final drafts of the personal experience recount texts were significantly different from the ones they wrote in the pretest. In account of having more opportunities to concentrate on language meaning and structure in the stage of de-contextualization and organization, the students could construct some more meaningful details into each section discussed as the essential component of the personal experience recount text in the literature review.

Significantly, their final drafts of personal experience recounts in the posttest have 'conformity' and 'compatibility' codifying the purpose and generic structuring of the modeling text provided. Their generic structure of the personal experience recount texts consisted of three main stages. They began with Orientation with the elaboration of the beginning background of the recount. Then, the Sequence of the Events $\sim($ Event 1 with the details connected to the orientation, Event 2 with the connective details with the event 1, Event 3 with the connective details with the event 2, Event 4 with the connective details with the event $3, \ldots$ ) were elaborated. Finally, the Re-orientation presented the conclusion of the personal experience recount, possibly added with the writer's opinions about the whole story). These can be discussed in a complete generic structure model of the personal experience recount genre as: Orientation ${ }^{\wedge}$ Sequence of the Events (Event 1, Event 2, Event 3,... ^ Re-orientation with CODA (Martin, 1993; Christie, 2002; Hood, 2006). It is argued that the SFL genre-based approach causes the students' positive development in expanding more opinions, attitudes, rationales, decisions and arguments into more elaborative and complex situations.

To sum up, the EFL Thai students in secondary schools have to spend so much time to undertake with lexical and grammatical knowledge before working with the structure of the text and starting to write a text. This causes the teacher to make revisions with backward staged-teaching if any of students' writing problems are realized. Understanding of both generic structure and cultural context of the lan- guage used (Hammond \& Gibbon, 2001) in a particular text enhances the learner writers to mobilize effective goal-oriented organized texts. Therefore, to encourage the students to accomplish writing for communication is to engage them with social and cultural contexts embedded in the particular text so that the goal-oriented teaching and learning activities in genre-based approach would lead the students to write the text purposively as well as to construct the text structurally.

\section{RECOMMENDATIONS}

Regarding advantages of SFL genre-based approach to teaching writing for further research which focus on proto type texts and clarity of meaning making, EFL Thai secondary school students' writing should be developed at all levels related and in other similar context through promotion of personal experience recount writing. That is to say, certain beneficial factors, such as extensive time of practicing writing, vocabulary and grammatical concerns and learning writing with structural oriented texts, should be promoted through group work activities. From this current study, it is observable that the good students would help the low students as well when learning essential elements of language such as registers and situations embedded in the modeling text. Therefore, the more the students did these activities the more they felt confident before writing their texts independently. However, time constraint with only 20 weeks identified in the school's curriculum restrict-ed the teacher to manage everything under the six-staged cycling of teaching and learning writing. Thus, it is suggested that for further research, the activities in teaching and learning cycling of the genre-based approach should be more explicit by exposing both meaning and structure of the modeling text to the students to encounter as the background experiences before practicing to construct their own texts in the future. It is also recommended that time management for teacher in each step of teaching and learning cycle should be carefully planned to make sure that students have enough time to develop their writing skill more effectively.

\section{REFERENCES}

Callaghan, M., \& Rothery, J. (1993). Teaching factual writing. NSW: Metropolitan East Disadvantaged Schools Program, Erskineville.

Chinnawongs, S. (2001). In search of an optimal writing feedback strategy. PASAA, 3, 27- 39.

Christie, F. (2002). The development of abstrction in adolescence in subject English. In M. J. Schleppegrell, \& M. C. Colombi (Eds.), Developing advanced literacy in first and second languages: Meaning with power (pp. 45-66). Mahwah, N.J.: Lawrence Erlbaum Associates, Publishers.

Christie, F. (2005). Language education in the priamary years. Sydney: University of New South Wales Press.

Christie, F., \& Derewianka, B. (2008). School discourse: Learning to write across the year of schooling. London: Continuum. 
Christie, F., \& Maton, K. (2011). Disciplinarity: Functional linguistics and sociological perspectives. London: Continuum.

Christie, F., \& Unsworth, L. (2006). Developing dimensions of an educational linguistics. In J. Webster, C. Matthiessen, \& R. Hasan (Eds.), Continuing Discourse on Language: A Functional Perspective. London: Equinox.

Derewianka, B. (2003). Trends and issues in genre-based approach. RELC Journal, 34 (2), 133-149.

Droga, L., \& Humphrey, S. (2002). Getting started with funtional grammar. Berry: Target Texts.

Feez, S. (2002). Heritage and innovation in second language education. In A. M. Johns (Ed.), Genre in the classroom (pp. 47-68). Mahwah, NJ: Erbaum

Foley, J. (2005). English in Thailand. RELC Journal, 36 (2), 223-234.

Gibbon, P. (2007). Scaffolding language and scaffolding learning: Teaching ESL students in mainstream classroom: Language in learning across the curriculum Reading $2^{\text {nd }}$. South of Australia: The State of South Australia: Department of Education and Children's Services.

Halliday, M. A. (1994). An introduction to function grammar. $2^{\text {nd }}$ ed. London: Edward Arnold.

Halliday, M. A., \& Matthiessen, C. M. (2004). An introduction to functional grammar ( $3^{\text {rd }}$ ed.). London: Hodder Arnold.

Hammond, J., \& Gibbon, P.(2001). What is scaffolding? In Hammod, J. (eds.). Scaffolding: Teaching and learning in language and literacy education (pp. 1-14). Newtown, New South Wales: Primary English Teaching Association 2001.

Hood, S. (2006). The Persuasive Power of Prodies: Radiating Value in Academic Writing. journal of English for Academic Purposes, 5 (1), 37-49.

Hood, S. (2010). Appraisal Research: Evaluation in Academic writing. Long Palgrave: Macmillan.

Hyon, S. (1996). Genre in three traditions: Implications for ESL. TESOL Quarterly 30 (4): 693-722.

Johns, A. M. (Ed.). (2002). Genre in the classroom: Multiple perspectives. New Jersey: Lawrence Erlbaum Associates.

LUU, T. T. (2011). Teaching writing through genre-based approach. BELT Journal, 2 (1), 21-136.
Martin, J. R. (1993). Genre and literacy: modeling context in educational linguistics. Annual Review of Applied Linguistics, 13 (1), 141-172.

Martin, J. R. (1997). Analyzing genre: Functional parameters. Institutions: Social processs in the workplace and school (pp. 3-39). London: Cassell.

Martin, J. R., \& Rose, D. (2003). Working with discourse. London: Continuum.

Martin, J., \& Rose, D. (2007). Working with discourse: Meaning beyond the clause (2 $2^{\text {nd }}$ edition). London, New York: Continuum.

Martin, J. R., \& Rose, D. (2008). Genre relation mapping culture. London: Equinox.

Ministry of Education (2008). The core curriculum of besic education. Bangkok, Thailand Department of Curriculum and Instruction Development.

Padgate, W. (2008). Beliefs and opinon about English writing at a Thai university. PASAA, 42, 31-54.

Paltridge, B. (2001). Genre and the language learning classroom. Ann Arbor, MI: University of Michigan Press.

Payaprom, S. (2012). The impack of genre-based aprroach on English language teaching in EFL tertiary context in Thailand, Doctor of Education Thesis. Faculty of Education, University of Wollongong.

Srinon, U. (2011). A longitudinal study of developments in the academic writing of Thai university students in the context of a genre based pedagogy, $\mathrm{PhD}$ thesis, the university of Adelaide, Australia.

Syananondh, K., \& Padgate, W. (2005). Teacher intervention during the writing process: An alternative to providing teacher feedback on EFL academic writing in large classes. PASAA, 36, 67-87

Thompson, G. (2014). Introducing functional grammar, $3^{\text {rd }}$ edition. London and New York: Routledge.

Unsworth, L. (2006). E-literature for children: Enhance digital literacy learning. London: Routledge.

Widodo, H. (2006). Comparative writing. Journal for Language Teaching, 28 (1): 20-32.

Wiriyachitra, A. (2002). English language teaching and learning in Thailand in this decade. ThaiTESOL Focus, 15 (1), 4-9.

Yin, R. K. (2003). Case study research: Design and methods ( $3^{\text {rd }}$ ed.). Thousand Oaks, CA: Sage Publications, Inc. 